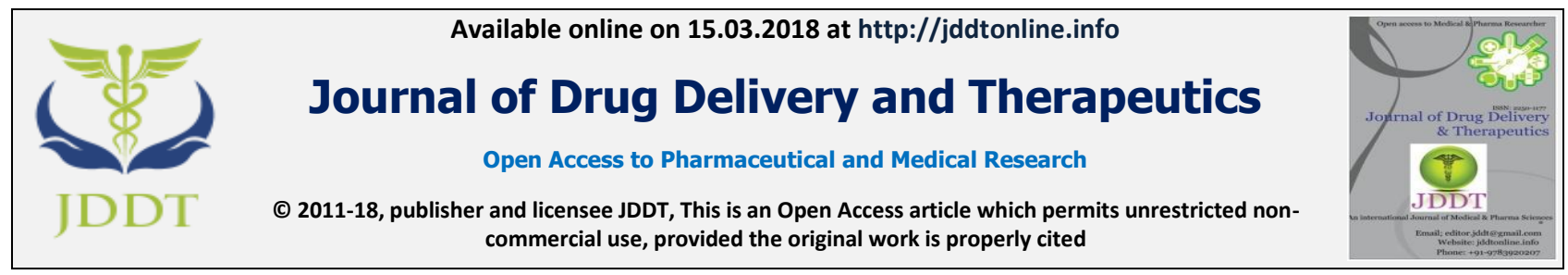

Open $\odot$ Access

Review Article

\title{
UNIFYING MECHANISM INVOLVING PHYSIOLOGICAL ACTIVITY OF SPICES: ELECTRON TRANSFER, REACTIVE OXYGEN SPECIES, OXIDATIVE STRESS, ANTIOXIDANTS, REDOX CHEMISTRY, AND FOODS
}

\author{
Peter Kovacic $^{1}$, Ratnasamy Somanathan ${ }^{2}$ \\ ${ }^{1}$ Department of Chemistry and Biochemistry, San Diego State University, San Diego, CA 92182-1030, USA. \\ ${ }^{2}$ Centro de Graduados e Investigación del Instituto Tecnológico de Tijuana, Apdo. postal 1166, Tijuana, B.C. Mexico.
}

\section{ABSTRACT}

This review deals with mode of action of spices. Those studied, involving principal ones and parent substances, together are the following; capsaicin (pepper, tabasco, jalapeño), curcumin (tumeric, ginger, curry), anethole (anise, fennel), myresticin (nutmeg, parseley, dill), sesamin (sesame) and piperine (pepper). These are in the phenolic and phenolic ether class, whereas allicin alone is in the disulfide category. Evidence supports the unfying mechanism of electron transfer, reactive oxygen species and oxidative stress for the seven. The disulfide is closely related via redox reaction without electron transfer. This review is an extension in relation to the unifying mode of action. Physiological and medical effects are treated

Keywords: Mechanism of action of spices, capsaicin, curcumin, sesamin, anethole, myresticin

\section{Cite this article as: Kovacic $\mathrm{P}$, Somanathan R, Unifying mechanism involving physiological activity of spices: electron transfer,

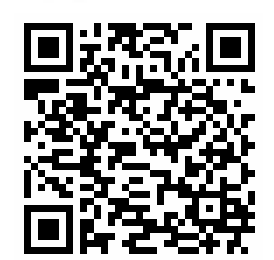 reactive oxygen species, oxidative stress, antioxidants, redox chemistry, and foods, Journal of Drug Delivery and Therapeutics. 2018; 8(2):146-152 \\ DOI: http://dx.doi.org/10.22270/jddt.v8i2.1732 \\ *Address for Correspondence: Peter Kovacic, Department of Chemistry and Biochemistry, San Diego State University, San Diego, CA 92182-1030, USA.}

\section{INTRODUCTION}

In early history, spices played an important role in trade, economy and exploration, as well as food flavoring and preservation, plus medicinal. A few years ago, a brief report was made on phenolic, natural product spices in relation to the unifying mechanism based on electron transfer (ET), reactive oxygen species (ROS) and oxidative stress (OS) ${ }^{1}$. The small number of monophenolics involved consisted of thymol (thyme), carvacrol (thyme, bergamot), eugenol (clove, nutmeg, basil), gingerol (ginger) and capsaicin (peppers), vanillin (vanilla), and sesamol (sesame) (Fig, 1).

The prepondence of bioactive substances, usually as metabolites, incorporate ET functionalities ${ }^{2}$. These may play an important role in physiological responses. The main group includes quinones (or phenolic precursors). Resultant redox cycling can occur, giving rise to OS through generation of ROS and diverse radicals (Scheme 1).

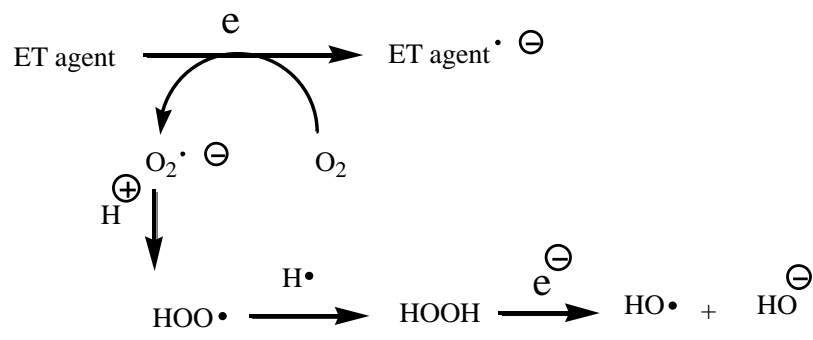

Scheme 1: Redox cycling with superoxide and ROS formation 
<smiles>Cc1ccc(C(C)C)c(O)c1</smiles>

Thymol<smiles>Cc1ccc(C(C)C)cc1O</smiles>

Carvacol<smiles>C=CCc1ccc(C)c(OCC)c1</smiles>

Eugenol<smiles>CCCCC[C@H](O)CC(=O)CCc1ccc(O)c(OC)c1</smiles>

Gingerol<smiles>COc1cc(CNC(=O)CCCC/C=C/C(C)C)ccc1O</smiles>

Capsaicin<smiles>COc1cc(C=O)ccc1O</smiles>

Vanillin

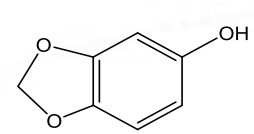

Sesamol
Figure 1: Naturally occurring phenols and phenol ethers

ROS and OS have been increasingly implicated in the mode of action of drugs and toxins. Phenols also display antioxidant (AO) properties. There is a plethora of experimental evidence supporting the ET-ROS theoretical framework. This evidence includes generation of the common ROS, lipid peroxidation, degradation products of oxidation, depletion of AOs, effect of exogenous AOs, and DNA oxidation and cleavage products, as well as electrochemical data. This comprehensive, unifying mechanism is consistent with the frequent observation that many ET substances display a variety of activities, such as multiple drug properties, as well as toxic effects. Phenols are one of the principal operators in spices. Mode of action in conversions to quinones is illustrated in Scheme 2. Phenolic ethers are also prevalent, which can undergo dealkylation to phenols.

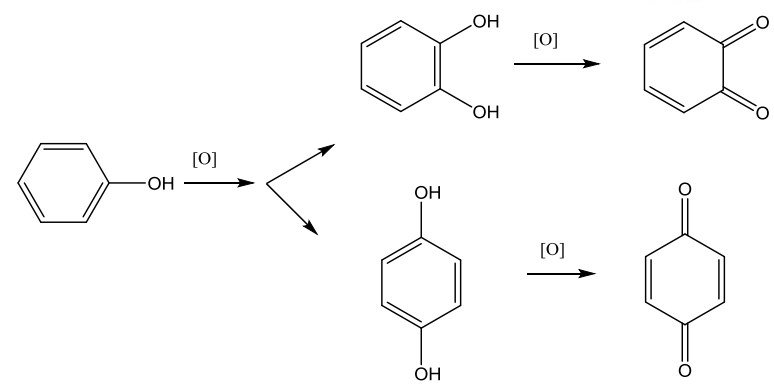

Scheme 2: Oxidative conversion of phenol to quinones

The literature contains reports on phenolic ethers acting as precursors of phenols. A quite relevant one involves the spice capsaicin which undergoes demethylation to a catechol type which is subject to subsequent oxidative transformation to an o-quinone ${ }^{1}$. Two possible routes exist, namely, acid catalyzed cleavage or oxidative radical dealkylation, the latter being the most likely. Scheme 3 provides the mechanism for the radical mode.

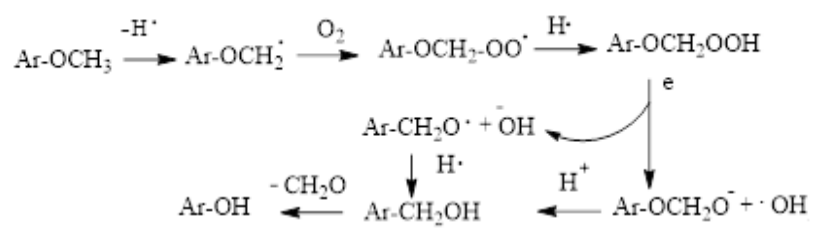

Scheme 3: Radical mechanism for phenol formation

This review is an extension of the prior one. Most of the spices fall in the phenols and/or the phenolic ether class. Physiological and medical effects are treated, in addition to the ET-ROS-OS mechanism.

\section{Capsaicin}

Capsaicin (Fig.2) is the main ingredient of various spices, such as pepper (red, chilli, and cayenne), tabasco and jalapeno. A recent book presents a detailed account of various aspects with emphasis on therapy ${ }^{3}$. The receptor, transient receptor potential vanilloid type-1 (TRPV1), responds to other stimuli including heat, protons and vanilloids. TRPV1 is involved in the control of pain and inflammation. The receptor is a nonselective cationic channel comprising expressed cells with excitable membranes, involving neurons which are capable of generating and propagating action potentials. Brain TRPV1 is associated with a wide array of functions and behavior in the central nervous system (CNS), including learning, memory and addiction. A section deals with capsaicin in the treatment of neuropathic pain. Studies indicate a role for the spice as an ant-obesity drug. Afferent nerves appear to play a role. Research supports the antitumor effects of capsaicin via induction of apoptosis. Apparently, the mechanism involves $\mathrm{Ca}$ increase, activation of transcription factors, disruption of mitochondrial membrane transition potential and generation of ROS which is in accord with the ET-ROS-OS unifying theme. The spice acts as therapy in dermatology involving neurogenic pain.<smiles>COc1cc(CNC(=O)CCCC/C=C/C(C)C)ccc1O</smiles>

Figure 2: Capsaicin.

Many of the physiological effects of capsaicin are based on the nervous system. A review presents a unifying electrochemical theme in the mechanism of the nervous system operation ${ }^{4}$.

A study of metabolites from capsaicin provides insight concerning mechanistic aspects, particularly in support of the ET-ROS-OS unifying theme. ${ }^{5}$. Oxidation by cytochrome $\mathrm{P} 450$ and peroxidase enzymes produced quinone methide and quinone products in addition to aromatic hydroxylation. Biomolecular coupling of free radical intermediates also occurred. The quinone metabolites can serve as ET agents in the formation of ROS and OS. The generated free radicals may play a role in the cytotoxic properties and pro-carcinogenic 
effects. The chemoprotective influence can be attributed to AO property of the phenolic portion.

Extensive literature exists involving ROS-OS to capsaicin action. In many cases, there is a connection with apoptosis as discussed in the following. The association may result from involvement of caspase-3 and formation of calcium ions ${ }^{6}$. AOs, such as catalase and a thiol type, largely prevented apoptosis generated by capsaicin-induced OS 7 . In another case, apoptosis resulted from participation of mitochondria in formation of ROS from capsaicin participation ${ }^{8}$. The possible involvement of NADPH oxidase in ROS production during the process was examined ${ }^{9}$.

There are considerable other articles on influence of ROS-OS in capsaicin systems. The chili components enhanced uptake of glucose in muscle cells via ROS involving the AMPK/p38 MAPK pathway ${ }^{10}$. Increased inflammation and OS from lipid peroxidation may interfere with cell processes, possibly leading to cell death ${ }^{11}$. Data indicate that certain receptors control the transduction of ROS by capsaicin-sensitive lung tissue ${ }^{12}$. A report deals with nerves sensitive to capsaicin and ROS in the pathology of gastric ulcers ${ }^{13}$. ROS mediated the development of hyperalgesia induced by capsaicin 14. The ROS-OS aspect plays a role in various other aspects of the physiological activity of capsaicin. There is a lessening of death of cancer cells via generation of ROS and depolarization of mitochondria ${ }^{8}$. Reports deal with involvement in the neural area ${ }^{15,16}$.

Substantial literature addresses use of capsaicin as an $\mathrm{AO}$ agent. It served as a powerful AO in lowering OS and blood LDL levels ${ }^{17}$. The spice constituent effectively decreased the generation of $\operatorname{ROS}^{18}$.

\section{Curcumin}

Curcumin (Fig.3), the principal agent of turmeric, is also a component of the ginger family and curry powder. It is related structurally to capsaicin in being a phenol type and undergoes tautomerism to the keto-enol form.

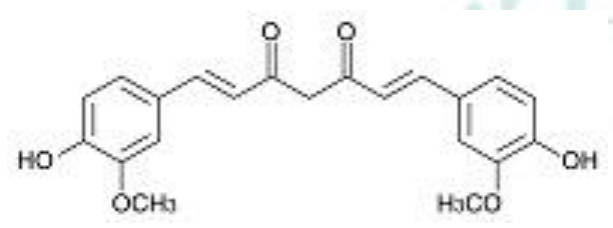

Figure 3: Curcumin.

The compound displays a broad spectrum of physiological and drug activities, of which representative examples are presented herein. In a study of chemopreventive and therapeutic effects, activity was shown as an anti-tumor, anti-inflammatory and antioxidant, capable of inducing apoptosis ${ }^{19}$. Mode of action is addressed in relation to carcinogenesis, gene expression and drug metabolism. Anti-inflammatory mechanisms are treated in a communication ${ }^{20}$. A brief review deals with antibacterial action, in addition to a broad range of other pharmacological properties ${ }^{21}$. The mechanism involves multiple targets. There is a report on anticancer properties and therapeutic activity 22 . Various biological aspects are involved, including mutagenesis, oncogenesis, apoptosis, tumorigenesis and metastasis. An anti-proliferation effect exists, in addition to metastasis. Turmeric is known to display antioxidant and antimicrobial properties ${ }^{23}$. A book reports on therapeutic use with attention to molecular targets ${ }^{24}$. Beneficial effects are reported for skin diseases, inflammation and urinary diseases.

Since there is structural relation, the ET-ROS-OS theory treated in capsaicin should also apply to curcumin. Phenols are known AO agents. There is also possible participation of the 1,3-diketo structure in mechanism, e.g., metal chelation with subsequent ET. A study is reported on $\mathrm{AO}$ activity. The two phenolic $\mathrm{OH}$ groups play major roles 25 . Electron transfer reactions are involved. There is a protective effect conferred by the $\mathrm{AO}$ in $\mathrm{Cd}$-induced $\mathrm{OS}$ and cardiovascular dysfunction 26. A beneficial influence occurred with curcumin against $\mathrm{Hg}$-induced $\mathrm{OS}$ in the liver ${ }^{27}$. The effect is attributed to free radical scavenging. These reports are representative examples of $\mathrm{AO}$ action.

Memory in people with Alzheimer's (AD) disease was improved ${ }^{28}$. The spice exerted various positive effects, including $\mathrm{AO}$ and anti-inflammatory. Evidence supports involvement of OS, free radicals, metal toxicity and inflammation. Curcumin has been investigated in treatment of cancer, ulcers, arthritis, liver disease and atherosclerosis. A recent review entails a role in inhibiting stem cancer cells ${ }^{29}$.

\section{Gingerol}

Gingrerol (Fig, 4), is an active ingredient of ginger and is chemically related to capsaicin ${ }^{30}$. The spice also contains 8-, 10- and 12- gingerols 31,32 . It and the analogs are active against cancer cells ${ }^{30-38}$ including those of blood and lung, as well as other organs.

Since the structure is similar to that of capsaicin, the chemical aspects should be related. Hence, the ET-ROSOS theme could be applied to gingers, including any AO effects.<smiles>CCCCC[C@H](O)CC(=O)CCc1ccc(O)c(OC)c1</smiles>

Figure 4: Gingerol.

Anise

Anethole (Fig. 5), a flavoring compound with an aromatic ether structure, is the principal active ingredient of anise and fennel. Anethole possesses a sweet taste and is used in alcoholic drinks, seasoning, confectionary applications and oral hygienic products ${ }^{39}$. The compound is a powerful antimicrobial agent against bacteria, fungi and yeast ${ }^{40}$. In antifungal action, it increases the effectiveness of phytochemicals ${ }^{41}$. Antihelmintic activity is exhibited in gastrointestinal nematodes of sheep ${ }^{42}$. Nemoanticidal action occurs against plant nematodes ${ }^{43}$. Anethole is an effective insecticide against the mosquito ${ }^{44}$ and other insects ${ }^{45-48}$. It also has activity as an estrogen ${ }^{49}$ and is present in the 
liquor absinthe ${ }^{50}$. Production of certain illicit drugs involves anethole as precursor ${ }^{51-53}$.<smiles>C/C=C/c1ccc(OC)cc1</smiles>

Figure 5: Anethole

\section{Myristicine}

Myristicine (Fig. 6), a phenolic ether is present in nutmeg, parsley and dill. It is a psychotic drug functioning as an anticholinergic and providing hallucinogenic effects, as well as intoxication ${ }^{54-56}$. Recreational use has caused poisoning ${ }^{57}$. Myristicine displays properties as an insecticide, acaricide (antiworm), anti-inflammatory, analgesic, neurotoxic, antibacterial, anti-fungal, anticonvulsant and antidiabetic agent ${ }^{58,59}$. A related work deals with anti-inflammatory properties related to the inhibition of NO, cytokines, chemokines, and growth factors in dsRNA-stimulated macrophages via the calcium pathway ${ }^{60}$. Nutmeg oil alleviates chronic inflammatory pain through inhibition of COX-2 expression in rat models ${ }^{61}$.

A study dealing with the comparison of natural myristicine as an effective insecticide against house fly and oriental cockroach was reported ${ }^{62}$. Two detailed reviews on Myristica fragrans and biological properties are reported ${ }^{63,64}$.

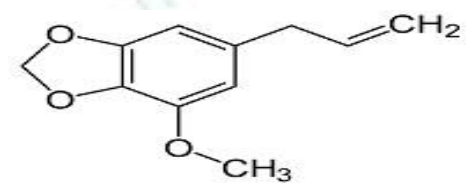

Figure 6: Myristicine.

\section{Sesamin}

Sesamin (Fig.7), a phenolic ether is isolated from sesame oil.<smiles>c1cc2c(cc1[C@@H]1OC[C@H]3[C@H]1CO[C@H]3c1ccc3c(c1)OCO3)OCO2</smiles>

Figure 7: Sesamin.

It exhibits antioxidant and anti-inflammatory properties 65. The article deals with the effect of sesamin on a model of Parkinson's disease. The effects consist of lower levels of malondialdehyde, a product of lipid peroxidation and ROS, improved superoxide dismutase activity, and apoptosis. Attenuation of OS took place. These findings are in accord with mode of action entailing ET-ROS-OS (see Introduction).

\section{Piperine}

In relation to other components of pepper, piperine (Fig. 8), a phenolic ether alkaloid, is responsible for the pungency of pepper and is also an insecticide. Evidence revealed increased generation of ROS in piperine-treated rectal cancer cells ${ }^{66}$. The AO N-acetylcysteine decreased apoptosis in the treated cells, demonstrating that the induced cytotoxicity was mediated by ROS, at least in part. A study showed piperine effectively protected primary cultured arterial monocytes from oxidative damage in rabbit model ${ }^{67}$. Cepharanthine and piperine act as antioxidants by inhibiting NF-kB and NLRP3 activation and halt the progression of diabetic nephropathy ${ }^{68}$. An investigation reported plant extract from Piper nigrum significantly reduced the OS status and ameliorated the neurodegeneration characteristic of Alzheimer's disease-induced rats ${ }^{69}$. Piperine, an antiinflammatory and antioxidant agent, provides neuroprotective action, making the drug a potential candidate for the treatment of neurodegenerative diseases such as Parkinson's 70, 71. A similar investigation showed amelioration of cypermethininduced oxidative damage in rat brain ${ }^{72}$. A study demonstrated that piperine is an effective antitumor compound in vivo and in vitro studies, involving a breast cancer model ${ }^{73}$. Piperine shows anti-inflammatory, antinociceptive, and antiarthritic effects in an arthritis induced animal model ${ }^{74}$. Piperine attenuates acetaminophen-induced hepatotoxicity in mice, comparable to the standard drug silymarin ${ }^{75}$. Several reviews highlight the therapeutic potential and biological role ${ }^{76,77}$.

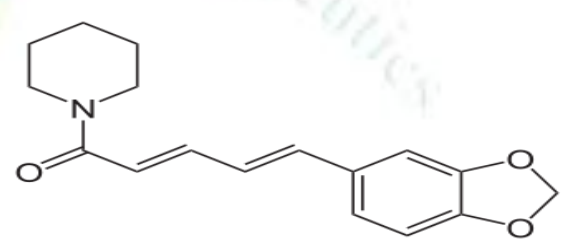

Figure 8: Piperine

\section{Allicin}

Allicin (Fig. 9), a thiosulfinate compound present in garlic, possesses a wide spectrum of bioactivity ${ }^{78}$. It is generated from the precursor allium (s-allylcystine sulfoxide).

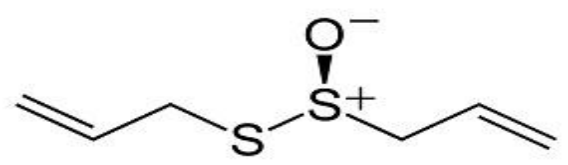

Figure 9: Allicin

It is different from many other spices, in not belonging to the phenolic or phenolic ether classes. Allium undergoes redox reaction with thiols present in glutathione (GSH) and proteins, which is believed to be a key element in the biological action. It exhibits activity against bacteria and fungi. In mammalian cancer cells, the compound can destroy the cells or inhibit proliferation. There is advantageous use for the cardiovascular system. Allium demonstrates widespread applications in medicine and agriculture. The majority of the effects appear to involve redox mechanisms. The enormous potential is evident; results clearly demonstrate that allium is the active anticancer agent in garlic ${ }^{79}$. The antimicrobial effect is due to interaction with thiol ${ }^{80}$. 
There is detailed treatment of the antifungal properties of allium and its metabolites ${ }^{81}$. The derivative allitridium demonstrated impressive activity against a wide range of fungi. Also, there is synergy with amphotericin B, an important antifungal agent. Glutathione, an antioxidant thiol, prevents damage to the cell. Activity is reported against bacteria, viruses and parasites. A common mode of action appears to exist. Garlic and diallyl trisulfids displayed high activity against cancer cells. The S-S- bonds appear to be necessary for activity. Supporting evidence is provided by the order of activity against bacteria: diallyl trisulfide $>$ dially disulfide > diallyl monosulfide. The biological effectiveness of allicin is likely due to its reactivity with thiol groups of tumor proteins and amino acids, as is illustrated in Scheme 4.

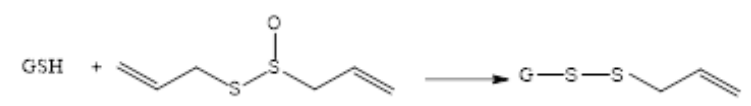

Scheme 4: Reaction of GSH with allicin.

Another report addresses the anti-inflammatory responses in addition to cancer chemoprevention ${ }^{82}$. The

\section{REFERENCES}

1. Kovacic P, Somanathan R, Abadjian M-CZ, Natural monophenols as therapeutics, antioxidants and toxins: electron transfer, radicals and oxidative stress. Nat. Prod. J. 2015; 5:142-151.

2. Kovacic P, Somanathan R, Mechanisms of conjugated imine and iminium species, including marine alkaloids: electron transfer, reactive oxygen species, therapeutics and toxicity. Curr. Bioact. Compds. 2010; 6:46-59.

3. Abdel-Sala, D. M.E. Edit., Capsaicin Acts as a Therapeutic Molecule Springer, New York, 2014, 1-317.

4. Kovacic P, Somanathan R, Electrochemical Involvement in the Senses. Adv Biochem Biotechl.: ABIO-144. 2017. DOI: 10.29011/2574-7258. 000044

5. Reilly CA, Henion F, Bugni TS, Ethirajan M, Stockmann C, Pramanik SK, Srivastava SK, Yost GS, Reactive intermediates produced from the metabolism of the vanilloid ring of capsaicinoids by p450 enzymes. Chem. Res. Toxicol. 2013; 18:55-66.

6. Naziroĝlu M, Övey IS. Involvement of apoptosis and calcium accumulation through TRPV1 channels in neurobiology of epilepsy. Neurosci. 2015; 293:55-66.

7. Pramanik KC, Boreddy SR, Serivatava SK. Role of mitochondrial electron transport chain complexes in capsaicin mediated oxidative stress leading to apoptosis in pancreatic cells. PlosOne 2011, 6: e20151.

Doi:19.137/journal.pone.0020151

8. Yang Z-H, Wang X-H, Wang H-P, Hu H-P, Hu L-Q, Zheng

$\mathrm{X}-\mathrm{M}$. Capsaicin mediates cell death in bladder cancer T24 cells through reactive oxygen species production and mitochondria depolarization. UROLOGY 2010; 75:735-741. Doi: 10.1016.j.urology.2009.03.042.

9. Lee YS, Kang YS, Lee J-S, Nicolova S, Kim J-A. Involvement of NADPH oxidase-mediated generation of reactive oxygen species in apoptotic cell death by capsaicin in HepG2 human hepatoma cells. Free Rad. Res. 2004; 38:405412.

10. Kim S-H, Hwang J-T, Park H-S, Kwon DY, Kim M-S. Capsaicin stimulates uptake in $\mathrm{C} 2 \mathrm{C} 12$ muscle cells via the reactive oxygen species (ROS)/AMPK/p38 MAPK pathway. Biochem. Biophys. Res. Commun. 2013; 439:66-70.

11. Luman S, Rizvi SI. Protection of lipid peroxidation and carbonyl formation in proteins by capsaicin in human erythrocytes subjected to oxidative stress. Phytoth. Res. 2006; 20:303-306. mechanistic studies appear to be in accord with part of the ET-ROS-OS approach involving the unifying theme. There is scarce discussion of the details of the unifying redox reports ${ }^{83,84}$, which are highly relevant. Mode of ROS-OS action occurs without ET. The peroxy radicals can serve as a source of other ROS. There is some discussion previously of oxidizing properties ${ }^{1}$. Scheme 5 is closely analogous to that of related peroxides.

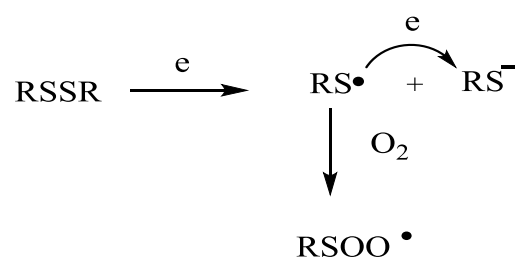

Scheme 5: Redox mechanism for disulfides

\section{Acknowledgements}

The assistance of Thelma Chavez and Dr. Wil Weston is acknowledged.
12. Ruan T, Lin Y-S, lin K-S, Kou Y-R. Sensory transduction of pulmonary reactive oxygen species by capsaicin sensitive vagal lung afferent fibres in rats. J Physiol. 2005; 565:563578. Doi: 10.1113/physiol.2005.086181.

13. Kwiecien $\mathrm{S}$. The role of reactive oxygen species and capsaicin-sensitive sensory nerves in the pathomechanisms of gastric ulcers induced by stress. J. Pysiol. Pharmacol. (Polish) 2003; 54:423-437.

14. Lee I, Kim HK, Kim JH, Chung K, Chung JM. The role of reactive oxygen species in capsaicin-induced mechanical hyperalgesia and in the activities of dorsal horn neurons. Pain 2007; 133:9-17.

15. Nakamura T, Onaga T, Kitazawa T. Ghrelin stimulates gastric motility of the guinea pig through activation of capsaicinsensitive neural pathway: in vivo and in vitro functional studies. Neurogastroentrol. 2010; 22:446-e107.

16. Barin AK, McDougall JJ. Endomorphin-1 causes synovial hypoamia in rat joints via a capsaicin-sensitive neural pathway. Neurosci. Lett. 2003; 344:21-24.

17. Lee C-YJ, kim M, Yoon S-W, Lee C-H. Short-term control of capsaicin on blood and oxidative stress of rats in vivo. Phytoth. Res. 2003; 17:454-458.

18. Drew H. 1066 Capsaicin reduces the production of reactive oxygen species by neutrophils. J. Allergy Clini. Immunol. 2000; 105:S362-S363.

19. Duvoix A, Blasius R, Delhalle S, Scnekenburger M, Morceau F, Henry E, Dicato M, Diedrich M. Chemopreventive and therapeutic effects of curcumin. Cancer Lett. 2005; 223:181190.

20. Gan Y, Zheng S, Baak JPA, Zhao S, Zheng Y, Luo N, Liao $\mathrm{W}, \mathrm{Fu} \mathrm{C}$. Prediction of the anti-inflammatory mechanisms of curcumin by module-based protein interaction network analysis. Acta Phamaceut. Sinica B 2015; 5:590-595.

21. Teow S-Y, Liew K, Ali SA, Khoo AS-B, Peh S-C. Anitibacterial action of curcumin against Staphylococcus aureus: a brief review. J. Trop. Med. 2016, doi:10.1155/2016/2853045.

22. Wilken R, Veena MS, Wang MB, Srivatsan ES. Curcumin: a review of anti-cancer properties and therapeutic activity in head and neck squamous cell carcinoma. Mol. Can. 2011; 10:12. Doi: 10.1186/1476-4598-10-12.

23. Gowda NKS, Ledoux DR, Rottinghaus GE, Bermudez AJ, Chen YC. Efficasy of turmeric (Curcuma longa), containing a known level of curcumin, and a hydrated sodium calcium 
aluminosilicate to ameliorate the adverse effects of aflatoxin in broiler chicks. Poultry Sci. 2008; 87:1125-1130. Doi: $10.3382 / \mathrm{ps} .2007-00313$.

24. Aggarwal BB, Surh Y-J, Shishodia S. Edi.,The Molecular Targets and Therapeutic Uses of Curcumin in Health and Disease. Springer, 2007.

25. Barzegar A. The role of electron-transfer and H-atom donation on the superb antioxidant activity and free radical reaction of curcumin. Food Chem. 2012; 135:1369-1376.

26. Kukongviriyapan U, Apijit K, Kukogviriyaapan B. Oxidative stress and cardiovascular dysfunction associated with cadmium exposure: beneficial effects of curcumin and tetrahydrocurcumin. Tohoku J. Exp. Med. 2016; 239:254-38.

27. Liu W, Li H, Yang T, Feng S, Xu B, Deng Y. Protective effects of curcumin against mercury-induced hepatic injuries in rats, involvement of oxidative stress antagonism, and Nrf2ARE pathway activation. Human Exp. Toxicol. 2016; 1-18. Doi: 10.1177/0960327116677355.

28. Shrikant M, Kalpana P. The effect of curcumin (turmeric) on Alzheimer;s disease: an overview. Acad. Neurol. Mumbai 2008, 11, 13-19.

29. Kovacic P, Somanathan R. Unifying mechanism for nutrients as anticancer agents: electron transfer, reactive oxygen species and oxidative stress. Global J. Heal. Sci. 2017, 9.

30. McGee H, A survey of tropical spices, McGee on Food and Cooking. Hodder and Stoughton, 2004, p.426.

31. Zick SM, Djuric Z, Ruffin MT, Litzinger AJ, Normolle SM, Alrawi S, Feng MR, Brenner DE. Pharmacokinetics of 6gingerol, 8-gingerol, 10-gingertol, and 6-shogaol and conjugate metabolites in healthy human subjects. Cancer Epidemiology Biomarkers and Prevention 2008; 17:19301936.

32. Park M, Bae, J, Lee DS. Antibacterial activity of 10-gingerol and 12-gingerol isolated from ginger rhizome against periodontal bacteria. PHYTOTHER. Res. 2008, 22, 14461449.

33. Semwal RB, Semwal DK, Combrink S, Viljoen AM. Gingerols and shogaols: important nutraceutical principles from ginger. Phytochemistry 2015; 117:554-568.

34. Jeong CH, Bode AM, Pugliese A, Cho Y-Y, Kim H-G, Shim J-H, Jeon YJ, Li H. 6-Gingerol suppresses colon cancer growth by targeting leukotrieneA4 hydrolase. Cancer Res. 2009, 69, 5584-5591.

35. Lee H, Seo E, Kang N, Kim W. Gingerol inhibits metastasis of MDA-MB-231 human breast cancer cells. J. Nutrit. Biochem. 2008; 19:313-319.

36. Rhode J, Fogoros S, Zick S, Wahl H, Griffith K, Huang J, Liu JR. Ginger inhibits cell growth and modulates angiogenic factors in ovarian cancer cells. BMC Comple, Alternat, Med. 2007; 7:44. Doi:10.1186/1472-6882-7-44

37. Zhang F, Thakur K, Hu F, Zhang JG, Wei ZJ. 10-Gingerol, a phytochemical derivative from"Tongling White Ginger", inhibits cervical cancer: insight into the molecular mechanism and inhibitory targets. J. Agric. Food Chem. 2017, 65;20892099.

38. Ramachandran C, Lollett IV, Escalon E, Quirin KW, Melnick SJ. Anticancer potential and mechanism of action of mango ginger (Curcumin amada Roxb.) supercritical CO2 extract in human gliblastoma cells. J. Evid. Based Complem. Altern. Med. 2015; 20:109-119.

39. Ashurst PR. Food Flavorings. Springer, 1999, p. 460.

40. De M, De AK, Sen P, Banerjee AB. Antimicrobial properties of star anise (Illicium verum Hook f). Phytother. Res. 2002; 16:94-95.

41. Fujita K, Fujita T, Kubo I. Anethole, a potential antimicrobial synergist, converts fungistatic dodeanol to fungicide agent, Phytother. Res. 2007; 21:47-51.

42. Camurça-Vasconcelos AL, Bevilaqua CM, Morales SM, Maciel MV, Costa CT, Macedo IT, Oliveira LM, Braga BR, Silva RA, Vieira LS. Anthelmintic activity of Croton zehntneri and Lippia sidoides essential oils. Vet. Parasitol, 2007; 148:288-294.

43. Oka Y, Nacar S, Putievsky E, Ravid U, Yaniv Z, Spiegal Y. Nematicidal activity of essential oils and their components against the root-knot nematode. Phytopathol 2000; 90:710715.

44. Knio KM, Usta J, Dagher S, Zournajian H, Kreydiyyeh S. Lavicidal activity of essential oils extracted from commonly used herbs in Lebanon against the seaside mosquito, Ochlerotatus caspius, Bioresour. Technol. 2008; 99:763-768.

45. Cheng SS, Liu JY, Tsai KH, Chen WJ, Chang ST. Chemical composition and mosquito larvicidal activity of essential oils from leaves of different Cinnamon osmorphloeum provenance. J Agric. Food Sci. 2004; 52:4395-4400.

46. Morais SM, Cavalcanti ES, Bertini LM, Olivera CL, Rodirigues JR, Cardoso JH. Larvicidal activity of essential oils from Brazilian Croton species against Aedes aegypti L. J. Am. Mosq, Control Assoc. 2006; 22:161-164.

47. Park IK, Choi KS, Kim DH, Kim LS, Bak WC, Choi JW, Shin SC. Fumigant activity of plant essential oils and components from horseradish (Armoracia rustican), anise (Pimpinella anisum) and garlic (Allium sativam) oils against Lycoriella ingenua (Diptera: Sciaridae). Pest Manag. Sci. 2006; 62,:723728.

48. Lee HS. Food protective effect of acaricidal components isolated from anise seeds against the stored food mite, Tyrophagus putrescenite (Schrank). J. Food Prot. 2005; 68:1208-1210.

49. Jordan VC. Estrogen/Antiestrogen Action and Breast Cancer Therapy. Univ. of Wisconsin Press. 1986, p. 21-22.

50. Lachenmeier DW. Thujone-attributable effects of absinthe are only an urban legend-toxicology uncovers alcohol as real cause of absinthism. Med. Monatsschr. Pharm. 2008, 31, 101106.

51. Waumans D, Bruneel N, Tytgat J. Anise oil as paramethoxyamphetamine (PMA) precursor. Forensic Sci. Int. 2003; 133:159-170.

52. Waumans D, Hermans B, Bruneel N, Tytgat J. A neolignantype impurity arising from the peracid oxidation reaction of anethole in the surreptitious synthesis of 4methoxyamphetamine (PMA). Forensic Sci. Int. 2004; 142:133-139

53. Benoni H, Dallakian P, Taraz K. Studies on the essential oil from guarana. Z. Lebensm Unters Forsch. 1996; 203:95-98.

54. Brenner N, Frank OS, Knight E. Chronic nutmeg psychosis. J. Royal Soc, Med. 1993, 86, 179-180.

55. Panayotopoulos DJ, Chisholm DD. Correspondence: hallucinogenic effect of nutmeg. British Med. J. 1970; 1:754 Doi: $10.1136 / \mathrm{bmj} .1 .5698 .754-\mathrm{b}$.

56. Williams EY, West F. The use of nutmeg as psychotropic drug. Report of two cases. J. Natn. Med. Assoc. 1968; 60:289290.

57. Baselt R. Disposition of Toxic Drugs and Chemicals in Man ( $8^{\text {th }}$. Edition). Foster City, CA. Biomedical Publications, 2008, pp. 1067-1068.

58. Lee BK, Kim JH, Jung J, Choi J, Han ES, Lee SH, Ko KH, Ryu JH. Myristicin-induced neurotoxicity in human neuroblastoma SK-N-SH cells. Toxicol. Lett. 2005; 157:49-56.

59. Asgarpanah J, Kazemivash H. Phytochemistry and pharmacologic properties of Myristic fragrans Hoyutt: a review. African J. Biotechnol. 2012; 11:12787-12793.

60. Lee JY, Park W. Anti-inflammatory effect of myristicin on RAW 254.7 macrophages stimulated with polyinosinicpolycytidylic acid. Molecules 2011; 16:7132-7142.

61. Zhang WK, Tao S-S, Li T-T, Li Y-S, Li X-J, Tang H-B, Cong R-H, Ma F-L, Wan C-J. Nutmeg oil alleviates chronic inflammatory pain through inhibition of COX-2 expression and substance $\mathrm{P}$ release in vivo. Food Nutri. Res. 2016; 60:30849. Doi: org/10.3402/fnr.v60,30849.

62. Świech K. Comparison of the insecticidal effectiveness of synthetic and and natural myristicin against housefly ( $M$ usca domestica L.) and oriental cockroach (Blatta orientalis). CHEMIK 2013; 11:1115-1120.

63. Nagja T, Vimal K, Sanjeev A. Myristica fragrance: a comprehensive review. Int. J, Pharmacy Phamaceut. Sci. 2016, 8

64. Jaiswal P, Kumar P, Singh VK, Singh DK. Biological effects of Myristica fragrans. ARBS Annua. Rev. Biomed. Sci. 2009; 11:21-29. 
65. Baluchnejadmojarad T, Mansouri M, GhLmi J, Mokhtari Z, Roghani M. Seasmin imparts neuroprotection against intrastrial 6-hydroxydomaimne toxicity by inhibition of astroglial activation, apoptosis and oxidative stress. Biomed. Pharmacother. 2017; 88:754-761.

66. Yaffe PB, Doucette CD, Walsh M, Hoskin DW. Piperine impairs cell cycle progression and causes reactive oxygen species-dependent apoptosis in rectal cancer cells. Exp. Mol. Pathol. 2012; 94:109-114.

67. Ma Y, Tian M, Liu P, Wang Z, Guan Y, Liu Y, Wang Y, Shan Z. Piperine effectively protects primary cultured arterial myocytes from oxidative damage in the infant rabbit model. Mol. Med, Rep. 2014; 10:2627-2632.

68. Samra YS, Said HS, Elsherbiny NM, Liou GI, El-Shishtawy MM, Eissa LA. Cepharanthine and Piperine ameliorate diabetic nephropathy in rats: role of NF- $\mathrm{kB}$ and NLRP3 inflammasome. Life Sci. 2016; 157:187-189-199.

69. Mahdy K, Shaker O, Nassar WY, Hassa H, Hussein A. Effect of some medicinal plant extracts on the oxidative stress status in Alzheimer's disease induced in rats. Eurp. Rev. Med. Pharmacol. Sci. 2012; 16:31-42.

70. Correia AO, Cruz AAP, de Aquino ATR, Diniz JRG, Santana KBF, Cidade PIM, Peixoto JD, Lucetti DL, Nobre MEP, da Cruz GMP, Neves KRT, de Barros Viana GS.

Neuroprorectuve effects of piperine, an alkaloid from the piper genu, on Parkinson's disease model in rats. J. Neurol. Theap. 2015; 1:1-8.

71. Yang W, Chen Y-H, Liu H, Qu H-D. Neuroprotective effects of piperine on the 1-methyl-4-pheny-1,2,36tetrahydropyridine-induced Parkinson's disease mouse model. Int. J. Mol. Med. 2015; 36:1369-1376.

72. Sankar P. Anitioxidant capacity of piperine on cypermethrininduced brain toxicity. Int. J. Sci. Environ. 2017; 6:1290-1293.

73. Lai L-H, Fu Q-H, Liu Y, Jiang K, Guo Q-M, Chen Q-Y, Yan B, Wang Q-Q, Shen J-G. Piperine suppresses tumor growth and metastasis in vitro and in vivo in a $4 \mathrm{~T} 1$ murine breast cancer model. Acta Pharmacol. Sinica 2012; 33:523-530.

74. Bang JS, Oh DH, Choi HM, Sur B-J, Lim S-J, Lim JY, Yang H-I, Yoo MC, Hahm D-H, Kim KS. Anti-inflammatory and antiarthritic effects of piperine in human inteleukin $1 \beta$ stimulated fibroblast-like synoviocytes and in rat arthritis models. Arthritis Res. Therap. 2009, 11. Doi:10.1186/ar2662.

75. Sabina EP, Souriyan ADH, Jackline D, Rasool, MK. Piperine, an active ingredient of black pepper, attenuates acetoaminophen-induced hepatotoxicity in mice. Asian Pacific J. Trop. Med. 2010, 971-976.

76. Wadhwa S, Singhal S, Rawat S. Bioavailability enhancement by piperine: a review. Asia J, Biomed. Pharmaceut. Sci. 2014; 4:1-8.

77. Copra B, Dhingra A, Kapoor RP, Prasad DN. Piperine and its various physiochemical and biological aspects: a review. Open Chem. J. 2016; 3:75-96.

78. Borlinghau J, Albrecht F, Gruhlke MCH, Nwachukwu ID, Slusarenko AJ. Allicin: chemistry and biological properties. Molecules 2014; 19:12591-12618.

79. Lee J, Gupta S, Huang J-S, Jayathillaka, Lee B-S. HPLC-MIT assay: anticancer activity of aqueous garlic extract from allicin. Analyt. Biochem. 2013; 436:187-189.

80. Ankari S, Mirelman D. Antimicrobial properties of allicin from garlic. Microbes Infec. 1999; 2:125-129.

81. Davis SR. An overview of the antifungal properties of allicin and its breakdown products-the possibility of safe and effective antifungal prophylactic. Mycoses, 2005, 48, 95-100.

82. Schäfer G, Kaschula CH. The immunomodulation and antiinflammatory effects of garlic organosulfur compounds in cancer chemoprevention. Anti-Cancer Agents Med. Chem. 2014; 14:233-240.

83. Antonello S, Benassi R, Gavioli G, Taddei F, Maran F. Theoretical and electrochemical analysis of dissociative electron transfers proceeding through formation of loose radical anion species: reduction of symmetrical and unsymmetrical disulfides. J. Am. Chem. Soc. 2002; 124:75297536.

84. Tama M, Simone G, Quintilini M. Interaction of thiol free radicals with oxygen: a pulse radiolysis study. Int. J. Radiat. Biol. 1986; 50:595-600. 